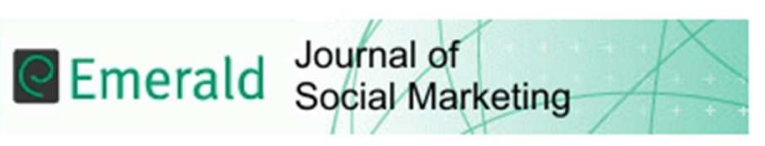

\title{
Value co-creation in social marketing: Functional or Fanciful?
}

\begin{tabular}{|r|l|}
\hline Journal: & Journal of Social Marketing \\
\hline Manuscript ID: & Draft \\
\hline Manuscript Type: & Conceptual Paper \\
\hline Keywords: & Social marketing, Value, Value co-creation, Participation \\
\hline \multicolumn{3}{c}{} \\
\multicolumn{3}{c}{ SCHOLARONE } \\
\multicolumn{3}{c}{ Manuscripts } \\
\end{tabular}




\section{Value co-creation in social marketing: Functional or Fanciful?}

\section{Introduction}

The move from goods-dominant logic to service-dominant logic, with an accompanying emphasis on the co-creation of value (see Lusch and Vargo, 2006; Vargo and Lusch, 2008a; 2008b; 2008c), is reshaping our understanding of markets and marketing. A central and fundamental concept of service-dominant logic is that value is only created when a product or service is consumed or used (Vargo and Lusch, 2004); as such it challenges directly the last 200 years of goods-dominant 4P thinking underpinning marketing exchange and conceptions of value as embedded in a product or service (Ballantyne and Varey, 2008). Greer and Lei's review of studies from several disciplines including: innovation, strategy, management, marketing and information technology, shows the increasing importance of various forms of collaboration (Greer and Lei, 2012) whereby co-creation of value has become the prevalent approach (Bilgram et al. 2011). For marketers and consumer researchers, the term has come to represent the many ways in which consumers and producers might collaborate to create value for mutual benefit (Schau, Muñiz, \& Arnould, 2009).

The move to value co-creation is not the only antecedent for the recent interest in more collaborative, participatory ways of working in social marketing (Collins et al., 2012; Bryant, et al., 2007). A rich and instructive heritage is woven through a variety of disciplines in the social and health sciences, such as education (Kemmis and McTaggart, 2005; Freire, 2000), public health (Israel et al., 1998), community development (Fals-Borda and Rahman, 1991), theology (Berryman, 1987) and international development (Chambers, 1997; Hickey and Mohan, 2005). In the UK, policymakers' attention is turning ever more to concepts such as Community Engagement, which assumes public services that involve their users are likely to be of higher quality and more relevant to the communities they serve (SCDC 2010), and Co-production, which posits that "people who use services contribute to the production of services" and is based on the insight that service users bring expertise and assets which can help improve those services (Needham and Carr 2009, p.4). There is also growing interest in what has been termed the Assets Based or 
Community Capacities approach (El-Askari et al., 1998; Kretzman and McKnight, 1996; Assets Alliance Scotland, 2010), focusing on a community's resources, skills, talents and ideas for generating change, rather than on their needs and deficits (Sharpe et al., 2000).

So what can be said of value co-creation for the social marketer? How can value be co-created in social marketing, if at all? Is the concept of value co-creation compatible with the social marketing principles of being client-led and collectively orientated? What might a value co-creation model look like in social marketing? And what are the challenges of adopting value co-creation in social marketing? This paper sets out to address these questions. Our aim is to contribute to the conceptual development of the field by highlighting some of the opportunities and dilemmas associated with using value co-creation to underpin behavioural and social change. We begin with a review of relevant literature to frame value co-creation in social marketing, much of which is optimistic about the potential for cross fertilisation. Next, we present an emerging social marketing value co-creation model, following which we discuss three substantive challenges in adopting value co-creation thinking. These challenges are: (1) ideological compatibility, (2) explanatory completeness, and (3) ethical conformity. We conclude that value co-creation in social marketing can be functional; it can represent an alternative to the prevalent goods-dominant, campaign oriented approach. However, we caution that current conceptualisations may be overly fanciful and advocate further construct development, especially from a collective and societal stance for 'solo social marketing flights'.

\section{Framing Value Co-creation in Social Marketing}

At first glance, value co-creation seems to be highly compatible with social marketing, both in theoretical terms and as an approach for designing and implementing programmes. According to Vargo and Lusch (2008), value co-creation may be "not only accommodative but potentially foundational" (p.6) to theory development in social marketing and is likely to have direct relevance to more general societal issues as well. 
Value co-creation in social marketing is, according to Kotler and Lee $(2008$, p. 7$)$, "a process that applies marketing principles and techniques to create, communicate, and deliver value in order to influence target audience behaviours that benefit society as well as the target audience". Thus, participants are engaged in joint analysis, development of strategy and structured learning to achieve behavioural change. Participants in co-created projects are assumed to partake deliberately in exchange instead of being "passive consumers of messages and programs" (Lefebvre, 2009, p.143). Further, conceptually value co-creation precedes and permeates every aspect of behavioural exchange (Lefebvre, 2012; Hastings and Domegan, in press). In simple terms, the social marketer is theorised as co-creating value in the form of dialogue, interaction, communication and collaboration with the target audience, in order to enhance the output value of favourable and desirable behaviours that the public are willing to adopt.

In addition to the fertile conceptual lens for theory building and testing offered by value co-creation, the potential benefits accruing from the active participation of the targeted communities are starting to attract increasing levels of interest from social marketers and from policymakers and programme designers in other fields. These benefits include 'consumer proofing' of interventions and an assumption of greater commitment to behavioural change (see Lefebvre, 2012; 2009; Holbrook 1999; Laczniak, 2006; Jackson 2005 and Hastings and Domegan in press). To this end it has been argued that third sector programmes "designed and directed by community members, are far more likely to succeed than those planned and executed exclusively by outsiders" (Bryant et al., 2000, p.61).

Value co-creation theory in social marketing rests upon people becoming direct and active participants in the change process. Hastings and Domegan (in press) break this down into:

i) Processes for value co-discovery (uncovering and exploring new types of value). Value co-discovery is founded in relationship marketing theory, which posits dialogue, interaction and mutual learning as core to value co-discovery. As Marques and Domegan (2011) explain, the intent is to build shared meanings and gain insight into what the parties can do together and for one another: thus, processes are used 
to give participants an active voice and research is conducted with and not on the participants.

ii) Processes for value co-design (designing valued products and services). Value codesign takes co-created knowledge from the value co-discovery process and translates it into jointly designed offerings. As part of the value co-design process, the social marketer and participant consider the appeal, affordability, availability and appreciation of the offer, and collaborate on ways to exemplify and enable the desired behaviour. These service-dominant logic ideas of co-production, copackaging, co-promotion and co-pricing recognise the important role of the participant.

iii) Processes for value co-delivery (taking i) and ii) to scale in a collectively coordinated strategy). With value co-delivery, the new, shared values between marketer and participants are brought together in a co-ordinated system [of delivery. The role of front-line staff is emphasised at this stage. The relevant system or combination of systems (for example, health, education, food, water, waste, transportation) has to facilitate, not block or hinder, the manifestation of the new initiatives for realising value, or they and the new behaviours cannot come into being. In its simplest form, value co-delivery processes should create value for all societal stakeholders (Ballantyne and Varey, 2006, Domegan, 2008 and Lusch and Webster, 2010).

FIGURE 1 HERE

\section{The Challenges of Adopting Value Co-creation Thinking}

Theoretically, then, value co-creation in social marketing would appear relatively straightforward, transferring easily as the literature and figure 1 above shows. But does value co-creation thought have (1) theoretical compatibility (2) explanatory completeness and (3) ethical conformity with social marketing principles and practice? To answer this question, we now turn our attention to these three distinct 
issues (see also Hasting and Saren, 2003; Wilkie and Moore, 2003; Diamond and Oppenheim, 2004; Layton, 2007).

Where relevant throughout the paper, we draw upon two examples of co-created projects where the authors have grappled with these challenges. Firstly, two linked projects in north and south Edinburgh in Scotland, seeking to combine social marketing with community development philosophy and practice (Stead et al., 2013). Each project was located in a low-income area identified for priority funding to promote healthier lifestyles, particularly in relation to diet and physical activity. Overseen by a steering group of health and local government practitioners, the two projects ran for 18 months and were coordinated by two community development workers, neither of whom had prior expertise in social marketing or public health. The projects were committed to using social marketing in a manner compatible with community development principles. This meant, for example, that local community members were integral to needs assessment, agreeing project objectives and developing project activities. The second example was commissioned as a 'social marketing intervention' by a Primary Care Trust in Gloucester, South West England, and has more recently been absorbed into wider community development work in the locality. The project aimed to understand why adults in two low-income neighbourhoods engaged in risky drinking practices and to co-create interventions to help them cut down. At the outset, it was assumed that providing information about safe drinking levels or attempting to educate people about the dangers of heavy drinking would probably be ineffective, even if this were done in a relevant and creative way. Instead, it was supposed that many factors in the social, economic and physical environment (such as access to employment) would influence drinking levels and that any intervention would need to acknowledge these. The next three sections deal with each of the three challenges of adopting value co-creation for social marketing.

The Challenge of Ideological Compatibility

Two areas of potential incompatibility are identified and discussed in this paper. The first relates to the risks of an uncritical transfer of value theory from commercial to 
social contexts, while the second deals with empowerment rhetoric and conceptualising the role of the expert in co-creation. Firstly, we suggest that making a simple, direct transfer of ideas about value and related conceptual developments from commercial to social marketing, without a thorough review of the implications of such a transfer, may be overly simplistic. To date, this question appears to have received little attention in the literature. Value is thought to be foundational to commercial marketing thinking because: a) value is created as an offering and delivered through recurrent transactions; b) value is created through mutually interactive processes and shared through negotiated agreement within the life of a relationship; and c) value emanates from interactions within relationships networks (Ballantyne et al., 2003). Thus, value is a consequence of openness, codetermination of the desired outcomes and the process of mutual and reciprocal learning. Tzokas and Saren (1997, p. 111) propose that value is "a relativistic (comparative, personal, situational) preference characterising a subject's experience of interacting with some object". Russell-Bennett et al. (2009) identify two approaches to conceptualising value in the marketing literature: economic and experiential. Economic value is the outcome of a cost-benefit analysis focused on the utility gained while experiential value is an interactive, relativistic preference experience. Grönroos (2004) argues that exchange should be considered relational and that value is both a determinant and a consequence of these relationships. Value in social marketing is "highly individualised, subjective and based upon experiences, actual and perceived" (Hastings and Domegan, in press) as Hastings and Lowry (2010, p.15) remind us, "values ascribed to the marketer's offering during an exchange may be tangible (e.g. monetary) or psychological (e.g. status); immediate (e.g. nicotine now) or deferred (e.g. better health later); but they will always be subjective". However, much of the behaviours social marketers are asked to tackle are in fact extremely complex with a multiplicity of inter-related system factors, what Domegan and Hastings (2012) present as 'wicked problems'. For example, with the alcohol work in Gloucester, participants in these very low income neighbourhoods would have valued having enough money to feed their children, feeling that they would be safe to walk outside at night and being provided with a 
doctor's surgery within walking distance. We could not in good conscience claim that our co-created social marketing programme could achieve these things. In fact, a critical reflection upon what value we actually did co-create in that project suggests that people valued the feeling that they had been listened to, their views taken seriously. Perhaps that is sufficient, and it is certainly better then leaving participants feeling that their lived experiences had gone unnoticed or unrecognised (as was the case with the iconic " 5 -a-day" campaigns so despised by the participants in this project). Nevertheless, this suggests that social marketers need to reflect critically upon the implications of adopting an ideology of value in their work, particularly when tackling complex societal threats such as inequality, obesity and sustainability. Secondly, there appears to be somewhat of a paradox in social marketing: for all its concern with 'customer orientation' and putting the consumer at the centre of the programme, most interventions appear to be designed and managed by experts rather than by the participants and communities who are their intended target groups and beneficiaries (Stead et al., 2013). Community members may be involved in intervention development as research participants (consulted about the acceptability and feasibility of the planned intervention, perhaps) or, less often, recruited to assist in programme implementation (for example, where 'lay people' are trained to facilitate particular activities or to act as recruiters for difficult-toreach target groups). Communities may also be involved in advisory and steering groups as lay or community representatives, but it is relatively rare for social marketing interventions to be designed and managed primarily by participants themselves (see also Middlestadt et al., 1997). In other words, despite apparent ideological compatibility between co-creation and social marketing, genuinely and fully co-created social marketing programmes are actually relatively rare. This may be reflect a reluctance to surrender the expert mindset (Chapman, 2004) or a fear among policy makers and managers of losing control over the intervention. More pragmatically, the perceived difficulty of mobilising communities to get involved may also be a factor. It must also be acknowledged that there is some risk that community members may decide to adopt an approach that experts believe will simply be wrong or ineffective. For example, members of the community who put 
themselves forward to participate may not necessarily be representative of the community as a whole or may have particular 'agendas' of their own, leading to the design of programmes which are potentially less appropriate and equitable than those led by professionals who have a commitment to equality practices. A community (or a vocal portion of one) may espouse approaches at odds with public health goals, social justice principles or evidence of effectiveness: what is the role of the expert in this situation? Do they assert their authority and intervene to steer the community towards more desirable and evidence-based activities? Finally, the language of co-creation implies that community members want (or ought to want) to be involved in the design and delivery of services. But, they may feel that this is an abdication of responsibility by professionals who are paid to do this work, or may suspect (perhaps rightly in some cases) that their unpaid involvement is being used as a way of cutting costs. Does empowerment include giving people permission to express a desire for the expert or service provider to take on the responsibility and effort to help individuals and communities? Can ordinary community members develop the same knowledge or expertise that professionals have (and if not, can they be said to be fully empowered)? It may be necessary for social marketers to accept that empowerment can only ever be partial, constrained, compromised. This may in fact be a more honest (and perhaps ultimately more empowering) position than embracing the belief that total empowerment is possible. If so, (and we think that this view has much to recommend it) we contend that the discourse should recognise and attempt to account for this complexity.

\section{The Challenge of Explanatory Completeness}

While value co-creation points to discursive and collaborative processes, these are situated theoretically at the downstream or individual level; consequently, value cocreation can be said to possess individualist explanatory power in the context of commercial marketing. But what of social marketing's collective orientation and explanatory insights to inform scability? We question the apparent juxtaposition of claims that co-creation involves close collaboration with participants to co-design valued solutions suitable for their particular circumstances with the requirements to 
develop social marketing theories and models of scalable strategies for change. Scaling up participant or community co-created interventions is extremely difficult, because the interventions are often so specific to the context in which they have been created. Consequently, another participant or community may have different priorities or prefer a different exchange. It can be contended that conceptually, replicability and scalability do not have relate to a particular co-created programme but instead any 'roll out' should be underpinned by successful processes of collaboration and co-design. However, value co-creation theory is rarely used to advocate mass customisation in its source domain of commercial marketing; instead this line of reasoning about scaling up participatory methods could suggest a greater similarity to Community Development than to marketing. There should always be room for alternative perspectives, but failing to appreciate this implication of transferring value co-creation from commercial to social marketing leaves proponents vulnerable to the charge that they are simply reinventing a Community Development wheel. This issue of whether value co-creation is considered to be a comparable or superior approach and in what circumstances has not been dealt with adequately in the literature. Finally, a more practical issue with scalability is the likely reliance, at least to some extent, on lasting sustainable structures for participation. As a consequence, funders may become somewhat dependent upon the willingness of community participants to commit to long-term involvement, which can be problematic because typically such participants are volunteers.

Between co-created social marketing programmes underpinned by theories of cocreation and the more established discipline of Community Development, several other areas of potential conflict exist: for example, the task of setting a precise behaviour change objective - one of Andreasen's (2002) six benchmarks of social marketing - is at odds with the principle of communities and individuals determining their own priorities, as well as with the emphasis placed in community development on wider, less measurable outcomes such as empowerment and social capital (Billings 2000). Unease about imposing project objectives may reflect wider conflicts in community development, such as the potential irreconcilability of community needs and funding agency expectations (Legge et al., 2007). In Edinburgh for 
instance, funders initially wanted to see activities linked to diet and physical activity with clear outcomes to be achieved within a short period of time. Developing a logic model, which specified that the main desired behavioural outcome was 'engagement' in community activities concerned with diet and physical activity rather than stipulating actual changes in diet and physical activity, helped to negotiate the tensions between the funders' requirements and community development principles. This made sure that the project had realistic goals and also made sense in terms of recognised evaluation frameworks like the Medical Research Council's framework for evaluating complex interventions, see Craig et al., (2008), which place the emphasis on assessing feasibility and engagement where interventions are exploratory or unpredictable, rather than on measuring behaviour change (the latter only applies where an intervention has been fully tested and tightly specified and rolled out on large scale). However, it should be recognised that such negotiations may not be successful; funders may be reluctant to finance programmes for more than a short period unless satisfactory results that demonstrate behaviour change are forthcoming.

In other respects, however, strong areas of complementarily are evident, with certain social marketing concepts thought to resonate strongly with a community development ethos. For example, 'consumer orientation' and 'mutually beneficial exchange' are seen as highly compatible with the community development principles of 'starting where the people are' (Lindsey et al., 2001). Equally the notion of addressing 'competition' in the form of structures and policies which are undermining of health - In Edinburgh, such issues included local retail practices and poor green space provision - sits comfortably with community development's concern with increasing disadvantaged communities' control over resources and services (Legge et al., 2007).

\section{The Challenge of Ethical Conformity}

Equating participation with empowerment, as value co-creation tends to do, has a number of implications for both theory and practice. Firstly, in a social rather than commercial context, methods that advocate participatory working may be chosen 
deliberately as a way to empower "surplus" (Hickey and Mohan, 2005, p.239) or "atrisk" populations (Pechmann, et al., 2011, p.23), i.e. groups that are likely to lack power, such as young people, inhabitants of deprived neighbourhoods, homeless people or sex workers for example. Thus, a methodological decision to collaborate with participants may arise from an aspiration to challenge inequalities in knowledge production (i.e. the formative research that so often underpins decision making when developing interventions) by giving voice to people normally excluded from the process (Gaventa and Cornwall 2001). Knowledge is considered by some to be an important source of power in post-industrial society (Ozanne and Saatcioglu, 2008), perhaps because research can serve as a metaphor for power and truth (Denzin and Lincoln, 2005); it is 'scientific'; its outputs are reports and representations of 'the Other'. Further, the premise that participation leads automatically to empowerment is not uncontested; indeed criticism that participation has failed to achieve this has been mounting over the last decade (e.g. Cooke and Kothari, 2001). It has been suggested that mainstream participatory methods may be hampered by inattention to issues of power and politics (Hickey and Mohan, 2005) exacerbated by the problem that such methods may be underpinned by an unsophisticated understanding of the mechanism and constitution of power (Mosse, 1994; Kothari, 2001). Also criticised are an overemphasis on local concerns to the detriment of pervasive problems of inequality (Mohan and Stokke, 2000) and a conceptualisation of the relative functions of structure and agency that is inadequate (Cleaver, 1999). Further, it has been argued that mainstream participatory approaches may be too voluntaristic in regarding any form of participation as superior to non-participatory practices (Chambers, 1997) without considering the risk that those with disempowering agendas may adopt (or co-opt) initiatives that serve their purposes (Rahman, 1995).

Finally, given the relatively short-term nature of many social marketing projects, Hickey and Mohan's (2005) caution against methodological individualism (Frances, 2001) that can arise from treating participation as a technical method of project work may be of concern. Participatory methods ought to be, they counsel, a political methodology of empowerment (Carmen, 1996; Rahman, 1995) and as such must 
include an appreciation of the issues that impede participation for marginalised groups. In the case of the alcohol work in Gloucester, participation was hampered by a number of factors: cynicism or 'participation fatigue' created in part by the number of short-term projects that had been set up and then disappeared once funding had been withdrawn, exacerbated by the feeling that outsiders with their " 5 -a-day" messages didn't understand what it was like to live in the community. Distrust of authority in general and an almost pathological fear of social services' involvement in their children's lives was a further barrier to participation. Underlying this, many local people were simply indifferent to the project and to the social marketers. Consequently, value co-creation requires very hard work to engage with a range of local people and even then, proponents must acknowledge that several years working in the community is needed before an empowerment claim can be made.

\section{Conclusions and implications}

For commercial marketers, value co-creation has represented somewhat of a shift in perspective from a goods-dominant logic towards a more collaborative understanding of value creation. In this paper, we have highlighted that the cooperative ambition suggested by co-creation theory seems to be highly compatible with social marketing in many ways. However, we have also noted some significant conceptual and practical obstacles in the path of a value co-creation theory for social marketing: Firstly, we have questioned whether a direct transfer of theories of value from commercial to social marketing is helpful. We have remarked that the notion of 'value' is somewhat rhetorical as in it carries with it an assumption of a positive outcome for all participants. We make no comment upon this question in the context of commercial marketing, but have noted that attempting to co-create value in social marketing situations frequently results in compromise of some sort, particularly when working within complex situations like the examples in this paper. That is not to say that value co-creation theory cannot or should not be used in social marketing, simply that more work is needed to explore the implications of the construct when co-creating social marketing strategies: does the idea of 'value' move closer to metaphor in more complex situations and if so what are the theoretical and practical consequences? 
Another compatibility challenge stems from a consideration of the role of the expert in co-creation. Similarly, the issue is concerned somewhat with the adoption of language from other disciplines and the related implication that co-creation is empowering for the individuals and communities involved. Arguing that participation is empowering isn't revolutionary (it is foundational to Community Development, for instance) but we have noted that social marketing interventions in which control over decision-making has been ceded to communities are relatively unusual. This may be due to well-founded concerns about whether those that volunteer for such projects are truly representative of (and should ethically be allowed to represent) their respective communities, whether participants have appropriate knowledge to co-create the most effective solution, whether funders are delegating responsibility inappropriately and whether volunteers are being exploited to help deliver services more cost effectively. A related issue concerns ethical considerations associated with the choice of participatory methods, particularly when a methodologically informed decision to collaborate is founded in a desire to co-create with people who may be disempowered, such as those living in deprived neighbourhoods. It has been suggested that empowerment ideals can be undermined by an inadequate consideration of the impact upon people of being disempowered, of the role of political and policy related factors and the danger of regarding any form of participation as automatically superior to non-participatory practices. Consequently, social marketers need to be sensitive to the reasons why people may not wish to participate, acknowledging that it can take considerable time to build relationships and trust to overcome an 'outsider' status (Sixsmith et al., 2003). Co-created social marketing should build in receptivity to power relations and politics, which can be complex and difficult to uncover, allied to a self-reflexivity among practitioners to guard against myopic judgements (e.g. see Lindridge, 2012). Finally, social marketers should empower themselves to negotiate with commissioners for adequate time, as well as to seek a commitment from commissioners that they will make long-term plans for the future of initiatives. To support this, evaluation should be multi-faceted and designed to reflect this long-term perspective upon change, as happened in Edinburgh. 
A further challenge relates to replicability and scalability of co-created social marketing programmes. We have pointed out that the very aspects of such programmes that make them attractive (that they are co-created with communities to serve their particular needs and aspirations) also make them very difficult to scale up. One solution might be to replicate successful processes for collaboration and cocreation, rather than rolling out a specific solution. However, scaling up participatory methods could suggest a greater similarity to participatory research or Community Development than to marketing. A half-way house between full scale community development and a traditional expert-led social marketing campaign could be to assume that social marketing strategies co-created by one group should probably work for people with similar characteristics: so the ideas co-created with the deprived neighbourhoods in Edinburgh and Gloucester should work in another deprived neighbourhood in, say, Manchester. The issues with this middle ground are twofold: firstly, the hypothetical community in Manchester will have had no say in the development or implementation of their programme, rendering the language of value and empowerment somewhat hollow. Secondly, experience suggests that almost inevitably, co-creation is influenced by local factors such as the presence (or absence) of amenities and services and the community's history. Even something as simple as the layout of the high street from one village to the next can result in completely different ideas.

An alternative may be to distinguish between participation in community development, an ongoing and very long-term process, and participation in time limited programmes and projects. In the latter case, imperatives and constraints are very likely to influence the nature of the participation, and not necessarily in a negative way. Arguably, the imperatives of a $n$ initiative subject to time and budgetary constraint can inject energy and bring people together in a more purposeful way; this was the case in both Edinburgh and Gloucester, where activities were structured around events and activities with very tangible outputs (for example, primary school children collectively producing a children's book in Edinburgh, Various, 2011, and a mobile service hub with street café in Gloucester, Collins and Manning, 2012) does seem to generate and focus energy. Perhaps the 
notion of value as the underpinning construct can serve to restrict social marketers to delivering a variety of small-scale programmes to reflect varying conceptions of value as part of a wider multi-disciplinary team?

These speculations leave a question that we are unable to answer satisfactorily at present: If we conclude that co-created social marketing is very similar to other ways of stimulating change through participation, why is co-created social marketing needed, why not just use Participatory Action Research or become an Asset Based Community Development practitioner? Emergent thinking has hinted at social marketing's creativity, flexibility and pragmatism (Collins, 2013) as worthwhile contributions to multi-disciplinary working aimed at tackling wider social issues. Further, we suggest that value co-creation in social marketing is not fanciful; rather it represents a promising alternative to the goods-dominant, campaign oriented approach prevalent in so much of mainstream social marketing literature and practice. However, current conceptualisations are vulnerable to accusations of narrow functionality, of an overly simplistic conceptualisation of value co-creation at the individual level. A more sophisticated model would seek to understand multiple levels and multiple perspectives; going beyond 'who' is involved in value co-creation to 'what' and 'how' value is exchanged from a collective and societal perspective (McHugh \& Domegan, in press). Perhaps this is where value co-creation has most to offer to a discipline that has reached adulthood. Thus, we are optimistic that value co-creation has the potential to provide focus and energy to what can otherwise be fairly slow moving processes of social change.

\section{References}

Andreasen, A. (2006) Social Marketing in the Twenty-First Century. London, UK, Sage Publications Inc.

Assets Alliance Scotland (2010). Assets Alliance Scotland. Scotland: Scottish Government/Scottish Community Development Centre (SCDC)/Long-Term Conditions Alliance Scotland (LTCAS). http://www.scdc.org.uk/news/article/Assets-alliance-scotland-report/

Ballantyne, D., Christopher, M., \& and Payne, A., (2003) Relationship Marketing: Looking Back, Looking Forward Marketing Theory, 3(1): 159-166. 
Ballantyne, D., \& Varey, R. (2008). The service-dominant logic and the future of marketing. Journal of the Academy of Marketing Science, 36, 11-14. London: Sage.

Ballantyne, D. \& Varey, R. (2006) Introducing a dialogical orientation to the servicedominant logic of marketing. In Lusch, R.F. and Vargo, S.L. (Eds) The Service Dominant Logic of Marketing: Dialog, Debate and Directions, New York, M.E. Sharpe, Inc., 224-235.

Berryman, P. (1987). Liberation Theology: essential facts about the revolutionary movement in Latin America and beyond. Philadelphia: Temple University Press.

Bilgram,V., Bartl, M., Biel, S. (2011). “Getting Closer to the Consumer-How Nivea CoCreates New Products." Marketing Review St. Gallen, Volume 28, Issue 1, pp. $34-40$.

Billings, J.R. (2000). Community development: A critical review of approaches to evaluation. Journal of Advanced Nursing, 31(2), 472-480.

Bryant, C. A., McCormack Brown, K. R., McDermott, R. J., Forthofer, M. S., Bumpus, E. C., Calkins, S. A., et al. (2007). Community-Based Prevention Marketing: Organizing a Community for Health Behavior Intervention. Health Promotion Practice, 8, 154-163.

Carmen, R. (1996). Autonomous Development. London: Zed Books.

Chapman, J. (2004) System Failure - Why Governments Must Learn to Think Differently, $2^{\text {nd }}$ Edition. London, UK, Demos.

Chambers, R. (1997). Whose reality counts? Putting the first last. London: Intermediate Technology Publications.

Cleaver, F. (1999). Paradoxes of Participation: Questioning Participatory Approaches to Development. Journal of International Development, 11, 597-612.

Collins, K (2013) "Reflection: Is there a role for marketing in Community Development?" Working paper invited by the editors of Community Development Journal, University of the West of England, 19 February 
Collins, K \& Manning, L (2012) “Co-creating with communities to understand and help solve the problems that lead to alcohol harm" Report prepared for NHS Gloucestershire.

Collins, K., Spotswood, F., \& Manning, L. (2012). Poverty, power and politics: considerations for engaging citizens in social marketing programmes . Lisbon: European social marketing Association.

Cooke, B., \& Kothari, U. (2001). Participation: The new tyranny? London: Zed Books. Craig, P., Dieppe, P., Macintyre, S., Michie, S., Nazareth, I., \& Petticrew, M. (2008). Developing and evaluating complex interventions: the new Medical Research Council guidance. BMJ .

Diamond, W. \& Oppenheim, M.R. (2004). Sources for Special Topics: Social Marketing, Nonprofit Organisations, Service Marketing and Legal/Ethical Issues. Journal of Business and Finance Librarianship, 9(4): 287-299.

Denzin, N. K., \& Lincoln, Y. S. (2005). The Discipline and Practice of Qualitative Research. In N. K. Denzin, \& Y. S. Lincoln, The Sage Handbook of Qualitative Research (3rd Ed.) (pp. 1-33). London: Sage Publications Inc.

Domegan, C. (2008) Social marketing: implications for contemporary marketing practices classification scheme. Journal of Business and Industrial Marketing, 23 (2), 135-141.Domegan, C. \&Hastings, G., (2012) "The DNA of societal value co-creation. Systems thinking social marketing" Taking Responsibility, Institute of social marketing Conference, Milton Keynes, 39-42.

El-Askari, G., Freestone, J., Irizarry, C., Kraut, K.L., Mashiyama, S.T., Morgan, M.A., \& Walton, S. (1998). The Healthy Neighborhoods Project: A Local Health Department's Role in Catalyzing Community Development. Health Education and Behavior, 25(2), 146-159.

Fals-Borda, O., \& Rahman, M. A. (1991). Action and Knowledge: Breaking the monopoly with Participatory Action Research. London: Intermediate Technology Publications. 
Frances, P. (2001). Participatory development at the World Bank: the primacy of process. In B. Cooke, \& U. Kothari, Participation: the new tyranny? (pp. 7287). London: Zed Books.

Freire, P. (2000). Pedagogy of the Oppressed. London: Continuum International Publishing Group.

Gaventa, J \& Cornwall, A (2001) Power and Knowledge, in P Reason and H Bradbury (Eds.), Handbook of Action Research: Participative Inquiry and Practice (7080) London: Sage Publications.

Greer, C. R. \& Lei, D. (2012)Collaborative innovation with customers: A review of the literature and suggestions for future research. International Journal of Management Reviews, 14: 63-83.

Gronroos, C. (2004) The relationship marketing process: communication, interaction, dialogue, value. Journal of Business and Industry Marketing, 19 (2), 99-113.

Hastings, G. \& Domegan, C. (in press) Social Marketing: Why Should the Devil Have all the Tunes? A few More Tunes, forthcoming $2^{\text {nd }}$ Edition, UK, Routledge.

Hastings, G. \& Lowry, R., (2010) Social Marketing: A tale of Beer, Marriage and Public Health, Chapter 20, Handbook of Behavioral Medicine: Methods and Applications, Methods and Applications Ed Steptoe, A. Springer, UK, London.

Hastings, G. \&Saren, M. (2003) The critical contribution of social marketing. Marketing Theory, 3 (3), 305-322.

Hickey, S., \& Mohan, G. (2005). Relocating participation within a radical politics of development. Development and Change , 36 (2), 237-262.

Holbrook, M. (1999). Introduction to Consumer Value in Consumer Value: A Framework for Analysis and Research, Morris B. Holbrook, ed. London, Routledge, 1-28.

Israel, B. A., Schulz, A. J., Parker, E. A., \& Becker, A. B. (1998). Review of CommunityBased Research: Assessing Partnership Approaches to Improve Public Health. Annual Review of Public Health , 19, 173-202.

Jackson, T., (2005) Motivating Sustainable Consumption: a review of evidence on consumer behaviour and behavioural change. A report to the Sustainable 
Development Research Network, DEFRA, UK.Kemmis, S., \& McTaggart, R. (2005). Participatory Action Research. In N. K. Denzin, \& Y. S. Lincoln, The Sage Handbook of Qualitative Research (3rd Ed.) (pp. 559-605). London: Sage Publications Inc.

Kothari, U. (2001). Power, knowledge and social control in participatory development. In B. Cooke, \& U. Kothari, Participation: The new tyranny? London: Zed Books.

Kotler, P. \& Lee, N. (2008). Social marketing: Influencing behaviours for good. Los Angeles: Sage.

Kretzmann, J., \& McKnight, J.P. (1996). Assets-based community development. National Civic Review, 85(4), 23-29.

Laczniak, G.R. (2006). Some Societal and Ethical Dimensions of the Service-Dominant Logic Perspective of Marketing in The Service-Dominant Logic of Marketing, Robert F Lusch and Stephen Vargo, eds. Armonk, NY:M./E Sharpe, 279-285. Layton, R.A. (2007) Marketing systems - a core macromarketing concept. Journal of Macromarketing, 27 (3), 227-242.

Lefebvre, R.C. (2009). The change we need: New ways of thinking about social issues. Social Marketing Quarterly, 15(3): 142-144.

Lefebvre, R.C. (2012) Transformative social marketing: co-creating the social marketing discipline and brand. Journal of Social Marketing, 2 (2), 118-129.

Legge, D.G., Gleeson, D.H., Wilson, G., Wright, M., McBride, T., Butler, P., \& Stagoll, O. (2007). Micro macro integration: Reframing primary healthcare practice and community development in health. Critical Public Health, 17(2),171-182.

Lindridge, A. (2012). Pandering to the middle-classes: is social marketing unethical? Taking Responsibility (pp. 75-76). Milton Keynes: ISM-Open.

Lindsey, E., Stjduhar, K., \& McGuiness, L. (2001). Examining the process of community development. Journal of Advanced Nursing, 33(6), 828-835.

Lusch, R.F. \& Stephen L. Vargo, S. L., (2006) The Service-Dominant Logic of Marketing: Dialog, Debate, and Directions. Armonk, NY: M. E. Sharpe. 
Lusch, R. \& Webster, F. (2010) Marketing's Responsibility for the Value of the Enterprise. Marketing Science Institute Working Paper Series 2010, Report No. $10-111$.

Marques, S. \& Domegan, C. (2011) Relationship marketing and social marketing. In Hastings, G., Angus, K. and Bryant, C. (Eds) The Sage Handbook of Social Marketing, London, UK, Sage Publication, 44-60.

McHugh, P. \& Domegan, C., (in press) "From Autocratic Governance to Collaborative Empowerment: A Social Marketing Approach to the Co-Creation of Policy" in Contemporary Issues in Social Marketing, Edited by Krzysztof Kubacki and Sharyn Rundle-Thiele, Cambridge Scholars Publishers, UK

Middlestadt, S.E., Schechter, C., Peyton, C., \& Tjugum, B. (1997). Community involvement in health planning: Lessons learned from practicing social marketing in a context of community control, participation and ownership. In Goldberg, M.E., Fishbein, M., \& Middlestadt, S.E. (eds.), Social Marketing Theoretical and Practical Perspectives. Mahwah, New Jersey: Lawrence Erlbaum Associates.

Mohan, G., \& Stokke, K. (2000). Participatory Development and Empowerment. Third World Quarterly , 21 (2), 226-280.

Mosse, D. (1994). Authority, Gender and Knowledge: Theoretical Reflections on PRA. Development and Change , 25 (3), 497-526.

Needham and Carr 2009 http://www.developbromley.com/public/SelfDirectedSupport/Tools/SCIE.Re search.Briefing.31.pdf.

Ozanne, J. L., \& Saatcioglu, B. (2008). Participatory Action Research. Journal of Consumer Research , 35, 423-439.

Pechmann, C., Moore, E., Andreasen, A., Connell, P., Freeman, D., Gardner, M., et al. (2011). Navigating the central tensions in research on at-risk consumers: challenges and opportunities. Journal of Public Policy \& Marketing , 30 (1), 23-30. 
Rahman, M. A. (1995). Participatory Development: Toward Liberation or Cooptation? In G. Craig, \& M. Mayo, Community Empowerment: A Reader in Participation and Development (pp. 24-32). London: Zed Books.

Russell-Bennett, R., Previte, J. and Zainuddin, N. (2009) Conceptualising value creation for social change management. Australasian Marketing Journal, 17 (4), 211-218.

Schau, H. J., Muñiz, A. M., \& Arnould, E. J. (2009). How Brand Community Practices Create Value. Journal of Marketing , 73 (5), 30-51.

Scottish Community Development Centre (2010) “Community engagement...encouraging productive relationships between communities and public bodies" Available at: http://www.scdc.org.uk/communityengagement/ (accessed $19^{\text {th }}$ March 2013).

Sharpe P.A., Greaney M.L., Lee P.R. and Royce S.W. (2000). Assets-oriented community assessment. Public Health Reports 115(2-3): 205-211.

Sixsmith, J., Boneham, M. and Goldring J.E. (2003), Accessing the Community: Gaining Insider Perspectives From the Outside. Qualitative Health Research, 13: 578-589.

Stead M, Arnott L and Dempsey E (2013). Healthy heroes, magic meals and a visiting alien: Community-led assets-based social marketing. social marketing Quarterly, 19(1): 26-39.

Tzokas, N. \& Saren, M. (1997) Building relationship platforms in consumer markets: a value chain approach. Journal of Strategic Marketing, 5 (2), 105-120.

Vargo, S. L. \& Lusch, R.L., (2004) "Evolving to a new dominant logic for marketing." Journal of Marketing, 68 (January),1-17.

Vargo, S. L. \& Lusch, R.L., (2008a) "Why "service" ?" Journal of the Academy of Marketing Science 36, 25-38.

Vargo, S. L. \& Lusch, R.L., (2008b) "Service-Dominant Logic: Continuing the Evolution" Journal of the Academy of Marketing Science 36, 1-10.

Vargo, S. L. \& Lusch, R.L., (2008c) "From good to service(s): Divergences and convergences of logics" Industrial Marketing Management. 
Various (2011). Liam and the Alien. Edinburgh: WhiteWater Publishing Ltd. ISBN-10: 0956136850. ISBN-13: 978-0956136855.

Wilkie, W. \& Moore, E. (2003). Scholarly research in marketing: Exploring the 'four eras' of thought development. Journal of Public Policy and Marketing, 22(2): 116-146. 


\section{Page 23 of 23}

\section{Journal of Social Marketing}

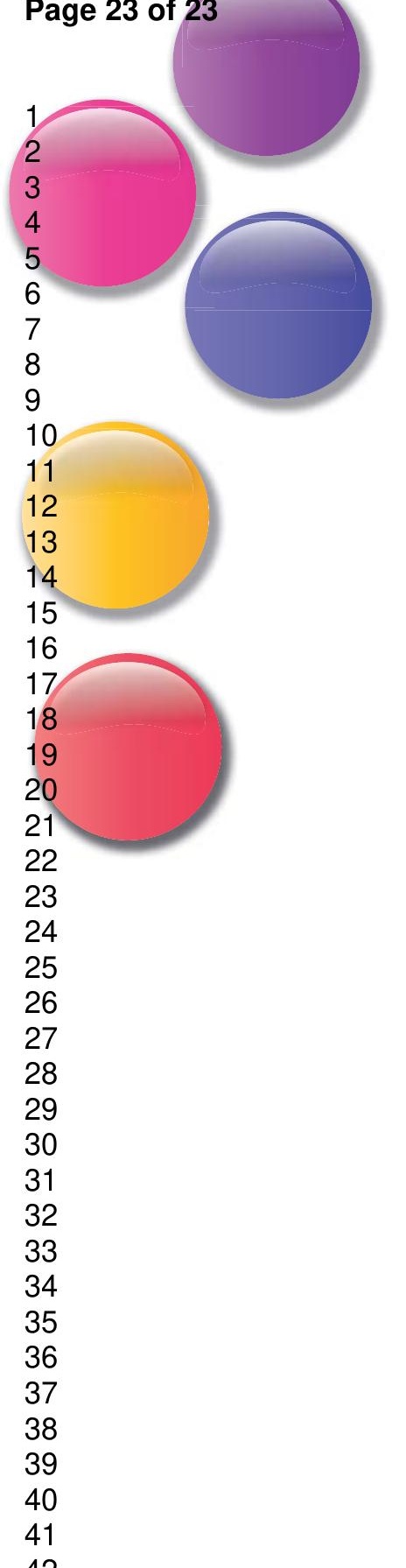

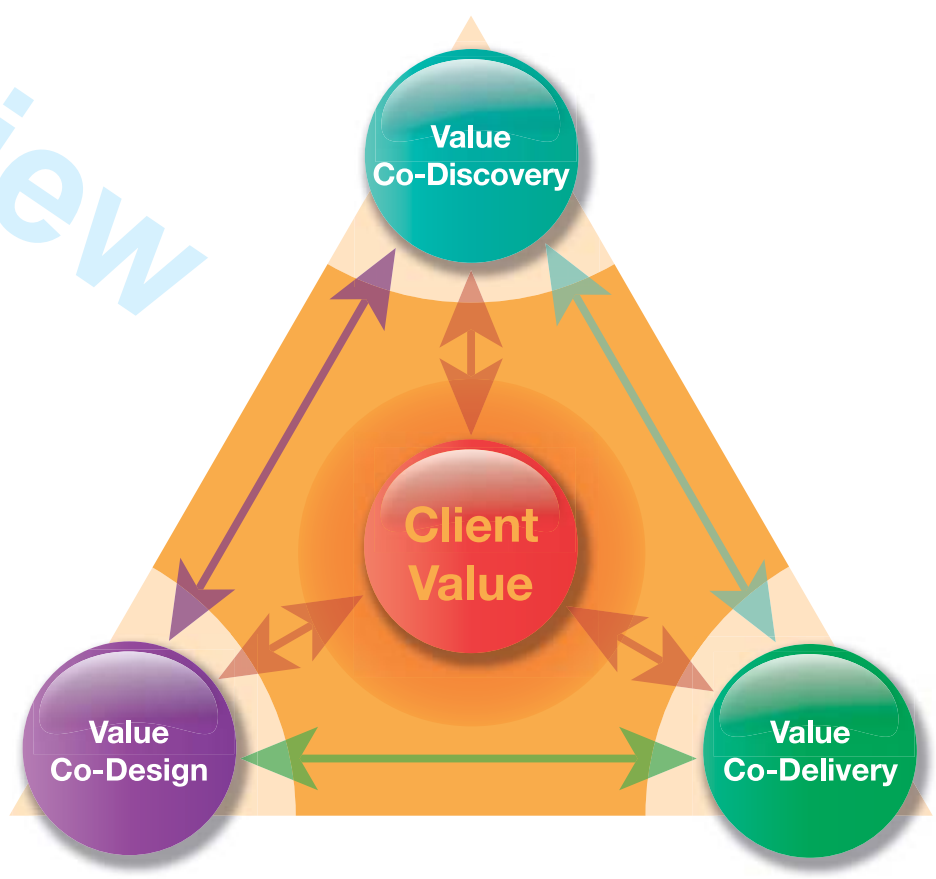

